Post-print version

DOI: $10.1007 / s 10311-017-0700-9$

Accepted: $15^{\text {th }}$ December 2017

Published: $28^{\text {th }}$ December 2017

Embargo period: 12 months

\title{
Does carbon limitation reduce nitrogen retention in soil?
}

\section{H. Kate Schofield ${ }^{a \neq}$, Tim R. Pettitt ${ }^{b \dagger}$, Alan D. Tappin ${ }^{a}$, Gavyn K. Rollinsonc, Mark F. Fitzsimons $^{\mathrm{a}^{*}}$}

\footnotetext{
${ }^{a}$ Biogeochemistry Research Centre, University of Plymouth, Drake Circus, Plymouth, PL4 8AA, UK

${ }^{\mathrm{b}}$ Eden Project, Bodelva, Cornwall, PL24 2SG, UK

${ }^{c}$ Camborne School of Mines, College of Engineering, Mathematics and Physical Sciences, University of Exeter, Penryn, Cornwall, TR10 9FE, UK.
}

¥ Current address: Foam Research and Development, Angus Fire, Station Road, High Bentham, Lancaster, LA2 7NA, UK

† Current address: Institute of Science and the Environment, University of Worcester, Henwick Grove, Worcester, WR2 6AJ, UK.

*Corresponding author

tel: +441752584555

fax: +441752584710

email: mfitzsimons@plymouth.ac.uk 


\begin{abstract}
Artificial soils made from waste materials offer an alternative to imported natural top-soils, notably in large-scale groundworks and reclamation projects. Benefits include diversion of waste from landfill and recycling. Nonetheless, there is limited information on the characteristics needed to support plant growth in the long-term, particularly the existence of a sustainable nitrogen reservoir. Therefore we assessed the efficacy of nitrogen cycling and retention within an artificial soil composed of $25 \%$ sand, $10 \%$ clay, $32.5 \%$ composted bark and $32.5 \%$ composted green waste over 52 weeks. Leachate was analysed for nitrogen species and nitrogen concentrations and two of the soil columns had fertiliser added after 26 and 48 weeks.

Results show that nitrate concentrations decreased from 6.73 to $0.36 \mathrm{mg} \mathrm{N} \mathrm{L}^{-1}$ after 2 weeks, due to poor retention of this anion in soil, and remained low for 6 months, before increasing up to $5.87 \mathrm{mg} \mathrm{N} \mathrm{L}^{-1}$ after week 26, in unfertilised soils. The sharp increase in dissolved nitrate was preceded by a decrease of the ratio of dissolved organic carbon over dissolved organic nitrogen in the soil leachate. This finding indicates that the soil had become carbonlimited, leading to mineralisation of organic nitrogen by soil organisms and excretion of nitrogen.

We also found that fertilisation of the soil with nitrogen-rich substrate did not alleviate carbon-limitation and nitrogen-loss was greater in fertilised soils, indicating nitrogensaturation. After the onset of carbon-limitation, the dissolved nitrate concentrations in both the fertilised and unfertilised soils were close to exceeding the European Union threshold of concern for nitrate groundwater and river pollution. Thus while the deployment of artificial soils is a viable option for landscaping projects, loss of nitrogen may be environmentally significant and soil management protocols must take account of both the carbon and nitrogen status of the substrate.
\end{abstract}




\section{Introduction}

Soil degradation is a critical and growing global problem. Increase in the world population has added to pressure on soil, and its natural capital faces continuing decline (Banwart, 2011; Koch et al., 2013). Dissolved and particulate soil constituents are lost by rainfall through leaching and erosion; one study estimated that soils in England and Wales had lost $0.6 \%$ carbon each year over several decades, in processes linked to climate change (Bellamy et al., 2005). Meanwhile, the complexity of soils creates significant challenges to establishing the robust science base needed to support key decisions on their future management.

Within the European Union (EU), the legislative framework on waste management is provided by the EU Waste Framework Directive (Directive 2008/98/EC), which sets the following waste hierarchy to be applied as a priority order in member states: prevention, preparing for reuse, recycling, other recovery and disposal. As such, disposal to landfill is the least favoured option meaning that a large amount of biodegradable waste must be diverted from landfills to other organic waste management practices, where it can be recovered and utilised.

Artificial soils are manufactured from waste materials. They are generally appropriate for urban development and landscape management, such as green areas, and as high value substrates (Koolen and Rossignol, 1998). Their uses include manufacture of topsoils for urban grasslands (Haraldsen et al., 2014), addition of waste sand as a soil amendment (de Koff et al., 2010), and materials for high (horticulture/agriculture) and low (amenity/restoration) value markets (Jones et al., 2009).

The chemical, physical and biological properties of artificial soils dictate their efficacy to support plant growth. Although, $\mathrm{pH}$, water holding capacity and biogeochemical properties of soils made from waste materials, such as nutrient levels and microbial biomass and activity, have been studied (Belyaeva and Haynes, 2009; Belyaeva et al., 2012; Dayton et 
al., 2010), there is limited information on the characteristics needed to support plant growth in the long-term. A key difference between artificial and natural soils is the predominance of largely compost-derived organic material in the former, while a natural topsoil contains approximately 95 \% inorganic matter (Speight and Lee, 2000). Soil organic matter comprises a number of components, namely 'inert' organic material, decomposable plant material, resistant plant material, microbial biomass and humified organic matter (White, 2006), the balance of which determines much of the availability of essential soil nutrients to plants. As such, a sustainable artificial soil must provide nutrients for plant growth, while maintaining inter alia a microbial population and cation exchange capacity (CEC) to balance nutrient loss through processes such as leaching. As nitrogen is an essential nutrient, limiting productivity in most terrestrial ecosystems (LeBauer and Treseder, 2008), one of the most significant requirements for an effective longer-term growth medium is its ability to retain, store and release this element as required to support plant growth cycles.

This study assessed the efficacy of nitrogen cycling within an artificial soil, deployed since 2000, within which a wide range of plants in a variety of natural and artificial environments have been grown. An amount of this substrate was freshly prepared and formed into soil columns; these were irrigated with $\mathrm{pH}$-adjusted high purity water for 52 weeks and the leachate systematically analysed over this period. Concentrations of nitrogen species in the leachate were quantified to evaluate the soil's efficacy in the storage and release of nitrogen and interpreted in the context of physico-chemical parameters. 


\section{Materials and methods}

Site description

The Eden Project is a visitor destination located in a reclaimed kaolinite pit in Cornwall, SW England, UK. Designed to celebrate the interdependence of plants and people and to educate people about the need to care for the world that cares for them (Treseder et al., 2011), it has been receiving visitors since 2001. The site contains three climatically- and ecologically-defined areas: two indoor biomes which span 2.2 ha and are housed under large greenhouse structures, and an outdoor biome of approximately 5.5 ha (Treseder et al., 2011). Each biome houses a diverse ecosystem, containing thousands of plant species from around the world. Since its inception in 2000, the Eden Project has used waste materials to construct an artificial soil, deploying 83,000 tonnes to date.

Soil composition

The artificial soil used in the experiments was identical to that deployed at the Eden Project. China clay sand, a by-product of the extraction of kaolin, was obtained from a local quarry (Goonvean, St Austell, Cornwall, UK). The grade used was classed as a 'horticultural grit' with an effective size $\left(\mathrm{ES}_{10}\right.$ - the sieve mesh through which $10 \%$ by weight of the sand would pass) of $0.45 \mathrm{~mm}$ and a uniformity coefficient (UC) of 3.07, calculated according to Equation 1

$$
\mathrm{UC}=\mathrm{ES}_{60} / \mathrm{ES}_{10}
$$

where $\mathrm{ES}_{60}$ was the sieve mesh size through which $60 \%$ by weight would pass. The sand was mixed with bark, composted green waste and lignite clay in volume proportions of 25, 32.5, 32.5 and $10 \%$, respectively. The mixture had a high organic matter (OM) content to facilitate nutrient cycling, through decomposition of both labile and recalcitrant OM, with composted 
green waste expected to decompose rapidly relative to more recalcitrant bark. The soil $\mathrm{pH}$ range was 6.2-6.8 and it had an air-filled porosity of $25 \%$. The soil classification was sandy loam according to ISO 14688-1.

Soil columns

Freshly-made artificial soil, S0, was packed into 4 tubes constructed from 110 x 1000 mm ( $\mathrm{d}$ x h) PVC pipe, as detailed in Schofield (2015). The moist mixture was packed into the tubes in layers of approximately $100 \mathrm{~mm}$, to a depth of $750 \mathrm{~mm}$. Each layer was compacted to replicate the bulk density of the soils in the Eden Project biomes. At the top of each column, a $100 \mathrm{~mm}$ layer of glass beads, each of $10 \mathrm{~mm}$ diameter, ensured that irrigation water was evenly delivered across the soil surface, while the lower $150 \mathrm{~mm}$ was packed with China clay sand to simulate a sub-soil and maintain flow within the column. The columns were opaque and capped to minimise light exposure.

The soil columns were irrigated according to the protocol employed for the indoor biomes at the Eden Project. The packed soil was initially left for 14 days at the experimental temperature, then drip irrigated with high purity water (HPW; $18.2 \mathrm{M} \Omega \mathrm{cm}$ ), adjusted to $\mathrm{pH}$ 7.0 , delivering $0.14 \mathrm{~cm}^{3} \mathrm{~cm}^{-2}$ day $^{-1}$ for the following 52 weeks. The columns were maintained at $15{ }^{\circ} \mathrm{C}$, which was within the average air temperature range of $11.3-16.2{ }^{\circ} \mathrm{C}$ measured between May and October, in nearby St Austell (https://www.yr.no/place/United_Kingdom/England/St_Austell/statistics.html).

Fertiliser was applied to two of the soil columns in Weeks 27 and 48 of the experiment using the manufacturer's recommended application rate of $20 \mathrm{~g} \mathrm{~N} \mathrm{~m}^{-2}, 9 \mathrm{~g} \mathrm{P} \mathrm{m}^{-2}$, $33 \mathrm{~g} \mathrm{~K} \mathrm{~m}^{-2}$. The fertiliser used by the Eden Project was Vitax® ${ }^{\circledR}$ 214, containing 4.5, 2.0, 7.5 $\% \mathrm{~N}, \mathrm{P}, \mathrm{K}$, respectively. It was a commercially available product composed of mainly organic 
materials; cocoa shell, fish meal, poultry litter, and gypsum. The unfertilised and fertilised columns were designated S1 and S2, respectively.

Sampling

Leachate was continually sampled at the base of each soil column, filtered through HPLC-grade glass fibre filters of $0.7 \mu$ m pore-size, then stored at $-20{ }^{\circ} \mathrm{C}$ prior to analysis, which was undertaken within 3 weeks of collection. Solid-phase measurements were performed on samples of freshly prepared artificial soil and after completion of the experimental period.

Physico-chemical measurements

The freshly manufactured, unfertilised and fertilised artificial soil and leachate samples were analysed for a number of physicochemical properties. Cation exchange capacity (CEC) was estimated for 2 depths within each profile using the ammonium acetate method (Schollenberger and Simon, 1945) at the beginning and end of the experiment. The $\mathrm{pH}$ of leachate samples was determined within 30 minutes of collection. The $\mathrm{pH}$ probe used was a standard glass electrode (VWR) with a Mettler Delta 340 milli-voltmeter, calibrated using buffer solutions of $\mathrm{pH} 4$ and 7, prepared with tablets dissolved in distilled water (Fisher Scientific).

Nutrient measurements

Aqueous phase: Concentrations of nitrate $\left(\mathrm{NO}_{3}{ }^{-}\right)$and nitrite $\left(\mathrm{NO}_{2}^{-}\right)$were measured using a Skalar SAN ${ }^{++}$nutrient analyser according to Kirkwood (1996); $\mathrm{NO}_{2}{ }^{-}$concentrations 
were found to be negligible. Ammonium $\left(\mathrm{NH}_{4}{ }^{+}\right)$was quantified using fluorescence spectrophotometry (Holmes et al., 1999). Concentrations of dissolved organic nitrogen (DON) were calculated by subtracting dissolved inorganic nitrogen (DIN) from total dissolved nitrogen (TDN), which was measured using a Shimadzu TNM-1 nitrogen module coupled to a Shimadzu TOC-V instrument; in this case DIN $=\mathrm{NO}_{3}{ }^{-}$as $\mathrm{NH}_{4}{ }^{+}$concentrations were below the limit of detection. Dissolved organic carbon (DOC) concentrations were directly measured by high temperature catalytic combustion using the Shimadzu TOC-V (Badr et al., 2003).

Solid-phase: Total particulate nitrogen (TPN) was analysed using an Elemental Analyser CHN EA1110 instrument according to Ryba and Burgess (2002). The proportion of nutrients susceptible to loss via rainwater leaching was determined through repeat extractions of soils with HPW at the beginning and end of the experiment, using an adaptation of the Bureau Common Reference extraction method (Little and Lee, 2010). A 4 g aliquot of soil was weighed into a centrifuge tube, to which $40 \mathrm{~mL}$ HPW was added. The tube was placed on an orbital shaker for 2 hours at $120 \mathrm{rpm}$, then centrifuged at $3000 \mathrm{rpm}$ for 5 minutes. The supernatant was removed and filtered through $0.7 \mu \mathrm{m}$ glass fibre filters and stored for analysis. A second $40 \mathrm{~mL}$ aliquot of HPW was added and samples were replaced on the rotary shaker; this process was repeated 3 more times for each sample. The filtrate was analysed for total extracted nitrogen (TEN), extracted organic nitrogen (EON) and extracted nitrate $\left(\mathrm{ENO}_{3}{ }^{-}\right)$; cumulative concentrations were also calculated from leachate data. 


\section{Results and discussion}

\section{Soil physico-chemical characteristics}

The cation exchange capacity (CEC) of the freshly prepared soil, S0, was $5.76 \pm 0.28$ $\mathrm{cmol} \mathrm{kg}^{-1}$; it decreased by $3 \%$ in the unfertilised soil, S1, but increased by $17 \%$ in the fertilised soil, S2, over 52 weeks. The CEC of the artificial soil was low compared with natural soils, which are in the range $12-20 \mathrm{cmol} \mathrm{kg}^{-1}$ (Brady and Weil, 2008). The $\mathrm{pH}$ of the soil decreased over time, from $6.62 \pm 0.51$ to $5.96 \pm 0.09$ (S1) and $5.74 \pm 0.04$ (S2) after 52 weeks (Figure 1). Although clay minerals normally contribute most sorption sites to soil (White, 2006), soil organic matter (SOM) also influences soil CEC through ionization of functional groups, such as carboxylic acids (Schwarzenbach et al., 1993). Assuming that the SOM functional groups contributing to CEC were carboxylate ions, the effect of the $\mathrm{pH}$ change can be estimated. If propanoic acid is used as a proxy $\left(\mathrm{pK}_{a} 4.87\right)$ then, for $\mathrm{S} 1$, the decrease of $0.66 \mathrm{pH}$ units would alter its ionised : unionised ratio from 56 to 12 , reducing the carboxylate abundance by more than $75 \%$.

Soil leachate

Nitrogen: Dissolved $\mathrm{NO}_{3}{ }^{-}$was the dominant inorganic $\mathrm{N}$ fraction in the leachate (Figure 2a); $\mathrm{NO}_{2}{ }^{-}$was assumed to be negligible throughout the experiment, while $\mathrm{NH}_{4}{ }^{+}$ concentrations were generally below instrument limits of detection. The dissolved $\mathrm{NO}_{3}{ }^{-}$ concentrations in the leachate decreased by $95 \%$, from 6.73 to $0.36 \mathrm{mg} \mathrm{N} \mathrm{L}^{-1}$, during the first 2 weeks of irrigation and concentrations remained below $0.63 \mathrm{mg} \mathrm{N} \mathrm{L}^{-1}$ until Week 27 (Figure 2a). From Week 2 onwards, dissolved organic nitrogen (DON) was the predominant form of $\mathrm{N}$ in the leachate (Figure $2 \mathrm{~b}$ ). Concentrations of DON decreased through Weeks 5 to 32, from 11.1 to $1.6 \mathrm{mg} \mathrm{N} \mathrm{L}^{-1}$, though at a slower rate than $\mathrm{NO}_{3}{ }^{-}$, and were never exhausted. 
From Week 27 onwards, concentrations of dissolved $\mathrm{NO}_{3}{ }^{-}$and $\mathrm{DON}$ increased in leachates of S1 and S2 columns, though higher mean values were measured in S2. Of the two fertiliser additions to S2, only the second application, at Week 48, significantly increased leachate $\mathrm{N}$ concentration compared with S1, based on a non-parametric Mann-Whitney U test $(\mathrm{p}<0.05)$.

The median error between replicate samples from the same column, during each sampling event, was $1.92 \%$ for $\mathrm{NO}_{3}{ }^{-}, 2.60 \%$ for total dissolved nitrogen (TDN), and $1.61 \%$ for DON in all columns. The $\mathrm{NO}_{3}{ }^{-}$and TDN standard deviation between columns increased significantly from Week 27; however, when considered as a percentage error for $\mathrm{NO}_{3}{ }^{-}$, a student's t-test demonstrated there to be no significant difference $(p>0.05)$ to the relative deviation between all replicate columns during Weeks 0-27, and S1 or S2 from Week 27 onwards. For TDN, a significant difference ( $\mathrm{p}<0.05$, student's t-test) was observed between columns S1 and S2 (i.e. unfertilised and fertilised) from Week 27 onwards.

Although treated identically during the preparation and monitoring process, with temperature and irrigation volume kept constant, each packed soil column was sealed from the surrounding environment and represented a discrete and isolated ecosystem. It is therefore proposed that the replicate inter-column variation in leached $\mathrm{N}$ concentrations measured from Week 27 onwards was the result of variation in the rates at which $\mathrm{N}$-cycling processes were occurring within each column.

Organic carbon: The initial dissolved organic carbon (DOC) concentrations in the leachate varied but a general increase was observed during Weeks 1 to 4, from $72 \pm 30$ to 272 $\pm 29 \mathrm{mg} \mathrm{C} \mathrm{L}^{-1}$, as shown in Figure 2c. During Weeks 4 - 14, concentrations decreased by 19.6 mg C L $\mathrm{m}^{-1}$ week $^{-1}$, and by $0.75 \mathrm{mg} \mathrm{C} \mathrm{L}^{-1}$ week $^{-1}$ during Weeks 29 - 52. Fertilisation had no significant effect on the DOC concentrations in leachates according to a non-parametric Mann-Whitney U test ( $\mathrm{p}>0.05)$. 
Solid-phase

Table 1 shows the S0, S1 and S2 solid-phase concentrations for $\mathrm{N}$-fractions and percentage changes after 52 weeks, based on mean column values, for S1 and S2 $(n=6)$. With the exception of $\mathrm{NO}_{3}{ }^{-}$in S2, concentrations of these fractions decreased over the experimental period. One-way ANOVA was used to determine the significance of differences between S0, S1 and S2 and showed that the concentrations of all $\mathrm{N}$-fractions were significantly different at the end of the experiment. However, addition of fertiliser had a significant effect only for total extractable nitrogen (TEN; one-way ANOVA, p < 0.036).

The average total soil mass within column at the beginning of the experiment was 9.53 $\mathrm{kg}$, of which approximately $2.38 \mathrm{~kg}$, or $25 \%$, was assumed to be moisture, based on the target moisture content for Eden Project soils. The total N reservoir of S1 was calculated to be $97.2 \mathrm{~g}$ at the beginning of the experiment, and $90.3 \mathrm{~g}$ at the end. Based on cumulative leachate $\mathrm{N}$ concentrations, an estimated $2.36 \mathrm{~g}$, or $2.4 \%$, of the total $\mathrm{N}$ reservoir was lost to leaching.

Using S1 leachate data, the estimated total leachate loss of $\mathrm{NO}_{3}{ }^{-}$from $\mathrm{S} 1$ was $295 \mathrm{mg} \mathrm{N}$, an amount almost ten times greater than the extractable $\mathrm{NO}_{3}{ }^{-}$concentration for $\mathrm{S} 0$, which was $31.5 \mathrm{mg}$ N. This indicated that leachate $\mathrm{NO}_{3}{ }^{-}$was principally an end product of $\mathrm{ON}$ mineralisation (Bingham and Cotrufo, 2016).

The extractable N, based on TEN concentration, was predominantly ON (Table 1), which is consistent with data reported for natural soils (Knicker, 2011; Lehmann et al., 2011; Rillig et al., 2007). In general, DON concentrations in pore waters of natural soils vary between 25 $\mu \mathrm{g} \mathrm{L}^{-1}$ and $10 \mathrm{mg} \mathrm{L}^{-1}$ (Perakis and Hedin, 2002; Vinther et al., 2006; Watson et al., 2000) and account for $0.1-3.0 \%$ of total soil $\mathrm{N}$ (Haynes, 2005). The DON concentrations in the S1 leachate over 52 weeks were, therefore, within the range expected for natural soils. 
Factors controlling N-cycling

A number of factors, both abiotic and biotic, are involved in the processing of $\mathrm{N}$ within soils. Considering N-levels within the S1 leachate, the first apparent change in composition was the rapid depletion of $\mathrm{NO}_{3}{ }^{-}$, which reduced in concentration by $95 \%$, to $0.36 \mathrm{mg} \mathrm{L}^{-1}$, after two weeks of irrigation, remaining at this level for 6 months. Such rapid loss occurs through poor retention of the anion in soil, meaning that DON was the dominant $\mathrm{N}$-fraction in S1 leachate from Week 2 onwards. After an initial increase, DON leachate concentrations decreased. The rate of flushing of ON from the soil, as DON, was much slower than for $\mathrm{NO}_{3}{ }^{-}$, probably reflecting a greater affinity of $\mathrm{ON}$ molecules for sorption sites (Lees et al., 2016), and removal, re-equilibration and repartitioning of sorbed ON as the experiment progressed. Several factors contribute to the adsorption capacity of a soil, including mineral and SOM content and the pH of soil pore waters (Lützow et al., 2006; Yu et al., 2013). Although some low molecular weight (LMW), highly-labile ON compounds, such as free amino acids, are rapidly utilised or transformed to other forms within the soil matrix (Farrell et al., 2011), $\mathrm{N}$ that has been stored in soils for centuries to millennia is, nonetheless, predominantly composed of LMW labile molecules (Bingham and Cotrufo, 2016). The pH decrease in the S1 soil likely reduced the number of available sorption sites for cationic LMW DON, while $\mathrm{H}^{+}$and metal cations would compete with ON molecules for remaining sites. Although $\mathrm{N}$ added to soils is rapidly stabilised, some of the stored $\mathrm{N}$ appears to be soluble (Lewis et al., 2014), which explained the presence of DON in the S1 leachate.

The elevated $\mathrm{NO}_{3}{ }^{-}$concentrations in $\mathrm{S} 1$ leachate after Week 26 endured until Week 52. The cumulative dissolved concentration of $\mathrm{NO}_{3}{ }^{-}$over 52 weeks exceeded the extractable $\mathrm{NO}_{3}{ }^{-}$concentration, indicating that dissolved $\mathrm{NO}_{3}{ }^{-}$was being formed via $\mathrm{ON}$ mineralization for $\mathrm{C}$. The timing indicates that this was a response to an imbalance of sequesterable $\mathrm{C}$ and $\mathrm{N}$ within the soil (Goodale et al., 2015), as a sharp decrease in the DOC : 
DON ratio occurred after 26 weeks in S1 columns (Figure 3). Bacteria have a lower $\mathrm{C}: \mathrm{N}$ ratio than fungi and were expected to dominate the microbial community during the first stages of the experiment. Previous direct microscope counts and measurements in the top 20 cm of Eden Project soil, 4 and 10 weeks after application of a green waste compost mulch, showed that bacterial biomass ranged between $7.60 \times 10^{5}$ and $1.58 \times 10^{7}$ propagules $\mathrm{g}^{-1}$ dry soil, while the fungal to bacterial biomass ratio ranged from 0.001 to 0.330 . When soils become C-limited, microbes will begin to utilize peptides and other small ON molecules as a source of C, excreting the excess $\mathrm{N}_{\text {as }} \mathrm{NH}_{4}{ }^{+}$(Farrell et al., 2013). As dissolved $\mathrm{NH}_{4}{ }^{+}$was not detected during the experiment any $\mathrm{NH}_{4}{ }^{+}$excreted to the soil would have been rapidly converted to $\mathrm{NO}_{3}$; the production of $\mathrm{NH}_{3}$ was assumed to be negligible as the $\mathrm{NH}_{4}{ }^{+}: \mathrm{NH}_{3}$ ratio at pH 6.62 was 429, increasing to 1960 at pH 5.96 - the starting and finishing $\mathrm{pH}$ for S1 leachate.

Fertilisation effects

Fertilisation of the columns during Weeks 27 and 48 affected both physico-chemical parameters and concentrations of N-species. The S2 leachate $\mathrm{pH}$ was always lower than for S1 after fertilisation (Figure 1); although this would have lowered the number of sorption sites, the CEC increased by $17 \%$ compared with S0. Thus, it would appear that the additional fraction of negatively-charged groups within the fertiliser more than compensated for any pH-associated CEC reduction.

Higher dissolved $\mathrm{NO}_{3}{ }^{-}$and $\mathrm{DON}$ concentrations were measured in S2 leachate after Week 27; for the former these levels were sustained until Week 52, while an increase in DON levels, compared with S1 leachate, was not apparent until after the second fertilisation in Week 48. Although the leachate concentrations of these N-fractions were higher in S2 than S1, the trend was similar. This indicates that the fertiliser additions did not supply enough C 
to alleviate the C-deficit and, as a result, appeared to exacerbate $\mathrm{N}$-loss as $\mathrm{NO}_{3}{ }^{-}$and labile DON.

Environmental implications

Certain aspects of $\mathrm{N}$-cycling in the artificial soil substrate studied were similar to reports for natural soils, particularly rapid loss of $\mathrm{NO}_{3}{ }^{-}$and the predominance of DON. However, dissolved $\mathrm{NO}_{3}{ }^{-}$concentrations increased after 26 weeks, and were sustained to the end of the experiment. The dissolved $\mathrm{NO}_{3}{ }^{-}$concentrations at this time were above 6 and $8 \mathrm{mg}$ $\mathrm{N} \mathrm{L}^{-1}$ for S1 and S2, respectively, approaching the EU threshold of concern for $\mathrm{NO}_{3}{ }^{-}$ groundwater and river pollution, which is $11.3 \mathrm{mg} \mathrm{N} \mathrm{L}^{-1}$ (Eurostat, 2012).

The large-scale deployment of artificial soils, such as the one studied here, represents an opportunity to both divert waste materials from landfill while reducing pressure on natural soils. Water leached from the Eden Project soils is channelled and monitored, and does not impact water quality once released from the site. However, the efficiency of N-storage may be a concern if deployment of this substrate, without modification, took place in areas where leached $\mathrm{N}$ would supplement nutrient levels in receiving waters. The variation in levels of leachate-N over the experimental period indicated that the soil had become C-limited after 26 weeks, leading to increased production of $\mathrm{NO}_{3}{ }^{-}$, while the extra $\mathrm{N}$ added in fertiliser applications probably caused the S2 columns to become N-saturated, so that the extra N was not sequestered. In these circumstances, we would recommend that the soil management protocol be reviewed to evaluate the efficacy of current fertilisation practice while considering addition of C-rich materials to improve sequestration of both carbon and nitrogen.

Conclusions 
We carried out the first biogeochemical study of $\mathrm{N}$ cycling in an artificial soil, made from waste materials, deployed as a high value substrate since 2000. While the CEC of the soil was low, dissolved $\mathrm{N}$ concentrations measured over 52 weeks were within the range reported for natural soils. For the first 26 weeks, the loss of N, measured in leachate, was related to low retention of $\mathrm{NO}_{3}{ }^{-}$and continual leaching of exchangeable, soluble DON. For the remaining 26 weeks, the elevated leachate $\mathrm{NO}_{3}{ }^{-}$concentrations appeared to be a response to C-limitation, a change likely to have increased ON mineralisation by soil organisms, with C retained and $\mathrm{N}$ excreted. This 'N-leakiness' appeared to be enhanced by addition of fertiliser, such that dissolved $\mathrm{NO}_{3}{ }^{-}$concentrations exceeded $8 \mathrm{mg} \mathrm{N} \mathrm{L}{ }^{-1}$, close to the $\mathrm{EU}$ threshold of concern for $\mathrm{NO}_{3}{ }^{-}$groundwater and river pollution.

In large-scale groundworks and reclamation projects, artificial soils made from waste materials offer a sustainable alternative to deployment of natural topsoils, and achieves diversion of waste from landfill, as required by the EU Waste Framework Directive. A sustainable reservoir of $\mathrm{N}$ is a key component of an artificial soil and this study indicates that the balance of $\mathrm{C}$ and $\mathrm{N}$ must be closely monitored so that management protocols address conditions leading to C-limitation and $\mathrm{N}$-saturation, both of which increase export of $\mathrm{NO}_{3}{ }^{-}$, and may impact water quality.

Acknowledgements

We are grateful for the comments of the Reviewers and Editors, which improved the manuscript considerably. The support of the Eden Project Green, Science and Foundation Teams is also gratefully acknowledged. This work was supported through a European Social Fund studentship awarded to HKS. 


\section{Figure Legends}

Figure 1. Temporal variation in leachate $\mathrm{pH}$ over the 52 weeks of the experiment; $\bullet=$ Weeks 0-26 for all columns, $\bullet=\mathrm{S} 1$ (Weeks 27-52), $\bullet=\mathrm{S} 2$ (Weeks 27-52). Measurements were made in triplicate on samples from each column. Leachate was collected from 4 columns ( $\mathrm{n}=$ 12) during Weeks 0 to 26 and in duplicate columns $(n=6)$ after Week 26. Vertical lines indicate times of fertiliser application. The $\mathrm{pH}$ of the soil decreased over time in all columns. S1 = unfertilised soil; S2 = fertilised soil

Figure 2. Concentrations of a) $\mathrm{NO}_{3}^{-}$, b) DON, c) DOC within the column leachate over 52 weeks; $\bullet=$ Weeks 0-26 for all columns, $\bullet=$ S1 (Weeks 27-52), $\bullet$ = S2 (Weeks 27-52). Analyses were performed in triplicate on samples from each column. Leachate was collected from 4 columns $(n=12)$ from Weeks 0 to 26 and on duplicate columns $(n=6)$ after Week 26. Dissolved $\mathrm{NO}_{3}{ }^{-}$was the dominant inorganic $\mathrm{N}$ fraction in the leachate. From Week 2 onwards, DON was the main form of $\mathrm{N}$ in the leachate (Figure 2b); its concentrations decreased during Weeks 5 to 32, though at a slower rate than $\mathrm{NO}_{3}{ }^{-}$. From Week 27 onwards, concentrations of dissolved $\mathrm{NO}_{3}{ }^{-}$and DON increased in leachates of both $\mathrm{S} 1$ and S2 columns, though higher mean values were measured in S2. A general increase in DOC was observed during Weeks 1 to 4; concentrations then decreased during the remaining weeks and fertilisation did not significant effect the DOC concentration. S1 = unfertilised soil; S2 = fertilised soil; $\mathrm{NO}_{3}{ }^{-}=$nitrate; $\mathrm{DON}=$ dissolved organic nitrogen; $\mathrm{DOC}=$ dissolved organic carbon.

Figure 3. Mean DOC : DON atomic ratio in S1 leachate over 52 weeks. A sharp decrease in the DOC : DON ratio occurred after 26 weeks. S1 = unfertilised soil; DOC = dissolved organic carbon; DON = dissolved organic nitrogen. 


\section{References}

Badr ESA, Achterberg EP, Tappin AD, Hill SJ, Braungardt CB (2003) Determination of dissolved organic nitrogen in natural waters using high-temperature catalytic oxidation. Trac-Trends in Analytical Chemistry 22:819-827.

Banwart S (2011) Save our soils. Nature 474:151-152.

Bellamy PH, Loveland PJ, Bradley RI, Lark RM, Kirk GJD (2005) Carbon losses from all soils across England and Wales 1978-2003. Nature 437:245-248. doi:http://www.nature.com/nature/journal/v437/n7056/suppinfo/nature04038_S1.html

Belyaeva ON, Haynes RJ (2009) Chemical, microbial and physical properties of manufactured soils produced by co-composting municipal green waste with coal fly ash. Bioresource Technology 100:5203-5209. doi:10.1016/j.biortech.2009.05.032

Belyaeva ON, Haynes RJ, Sturm EC (2012) Chemical, physical and microbial properties and microbial diversity in manufactured soils produced from co-composting green waste and biosolids. Waste Management 32:2248-2257. doi: 10.1016/j.wasman.2012.05.034

Bingham AH, Cotrufo MF (2016) Organic nitrogen storage in mineral soil: Implications for policy and management. Science of The Total Environment 551-552:116-126. doi:http://dx.doi.org/10.1016/j.scitotenv.2016.02.020

Brady NC, Weil RR (2008) The Nature and Properties of Soil, 14th ed. Prentice Hall, New Jersey, USA; 965 pp.

Dayton EA, Whitacre SD, Dungan RS, Basta NT (2010) Characterization of physical and chemical properties of spent foundry sands pertinent to beneficial use in manufactured soils. Plant and Soil 329:27-33. doi:10.1007/s11104-009-0120-0

de Koff JP, Lee BD, Dungan RS, Santini JB (2010) Effect of Compost-, Sand-, or Gypsumamended Waste Foundry Sands on Turfgrass Yield and Nutrient Content. Journal of Environmental Quality 39:375-383. doi:10.2134/jeq2008.0330

Eurostat (2012) Agri-environmental indicator - nitrate pollution of water http://ec.europa.eu/eurostat/statisticsexplained/index.php/Agrienvironmental_indicator_-_nitrate_pollution_of_water Accessed 8th March 2017.

Farrell M, Hill PW, Farrar J, Bardgett RD, Jones DL (2011) Seasonal variation in soluble soil carbon and nitrogen across a grassland productivity gradient. Soil Biology and Biochemistry 43:835-844. doi:http://dx.doi.org/10.1016/j.soilbio.2010.12.022

Farrell M, Hill PW, Farrar J, DeLuca TH, Roberts P, Kielland K, Dahlgren R, Murphy DV, Hobbs PJ, Bardgett RD, Jones DL (2013) Oligopeptides Represent a Preferred Source of Organic N Uptake: A Global Phenomenon? Ecosystems 16:133-145. doi:10.1007/s10021-012-9601-8

Goodale CL, Fredriksen G, Weiss MS, McCalley CK, Sparks JP, Thomas SA (2015) Soil processes drive seasonal variation in retention of $15 \mathrm{~N}$ tracers in a deciduous forest catchment. Ecology 96:2653-2668. doi:10.1890/14-1852.1

Haraldsen TK, Brod E, Krogstad T (2014) Optimising the organic components of topsoil mixtures for urban grassland. Urban Forestry \& Urban Greening 13:821-830. doi:10.1016/j.ufug.2014.05.004

Haynes RJ (2005) Labile organic matter fractions as central components of the quality of agricultural soils: An overview. In: Sparks DL (ed). Advances in Agronomy, Vol 85. pp 221-268

Holmes RM, Aminot A, Kerouel R, Hooker BA, Peterson BJ (1999) A simple and precise method for measuring ammonium in marine and freshwater ecosystems. Canadian 
Journal of Fisheries and Aquatic Sciences 56:1801-1808.

Jones DL, Chesworth S, Khalid M, Iqbal Z (2009) Assessing the addition of mineral processing waste to green waste-derived compost: An agronomic, environmental and economic appraisal. Bioresource Technology 100:770-777. doi:10.1016/j.biortech.2008.06.073

Kirkwood D (1996) Nutrients: Practical notes on their determination in sea water. International council for the exploration of the sea, Copenhagen. pp 25.

Knicker H (2011) Soil organic N - An under-rated player for C sequestration in soils? Soil Biology and Biochemistry 43:1118-1129. doi:http://dx.doi.org/10.1016/j.soilbio.2011.02.020

Koch A, McBratney A, Adams M, et al. (2013) Soil Security: Solving the Global Soil Crisis. Global Policy 4:434-441. doi:10.1111/1758-5899.12096

Koolen AJ, Rossignol JP (1998) Introduction to symposium 19: construction and use of artificial soils. Soil \& Tillage Research 47:151-155.

LeBauer DS, Treseder KK (2008) Nitrogen limitation of net primary productivity in terrestrial ecosystems is globally distributed. Ecology 89:371-379. doi:10.1890/062057.1

Lees K, Fitzsimons M, Snape J, Tappin A, Comber S (2016) Pharmaceuticals in soils of lower income countries: Physico-chemical fate and risks from wastewater irrigation. Environment International 94:712-723. doi:http://dx.doi.org/10.1016/j.envint.2016.06.018

Lehmann J, Rillig MC, Thies J, Masiello CA, Hockaday WC, Crowley D (2011) Biochar effects on soil biota - A review. Soil Biology and Biochemistry 43:1812-1836. doi:http://dx.doi.org/10.1016/j.soilbio.2011.04.022

Lewis DB, Castellano MJ, Kaye JP (2014) Forest succession, soil carbon accumulation, and rapid nitrogen storage in poorly remineralized soil organic matter. Ecology 95:26872693. doi:10.1890/13-2196.1

Little MG, Lee CTA (2010) Sequential extraction of labile elements and chemical characterization of a basaltic soil from Mt. Meru, Tanzania. Journal of African Earth Sciences 57:444-454. doi:https://doi.org/10.1016/j.jafrearsci.2009.12.001

Lützow Mv, Kögel-Knabner I, Ekschmitt K, Matzner E, Guggenberger G, Marschner B, Flessa H (2006) Stabilization of organic matter in temperate soils: mechanisms and their relevance under different soil conditions - a review. European Journal of Soil Science 57:426-445. doi:10.1111/j.1365-2389.2006.00809.x

Perakis SS, Hedin LO (2002) Nitrogen loss from unpolluted South American forests mainly via dissolved organic compounds. Nature 415:416-419.

Rillig M, Caldwell B, Wösten H, Sollins P (2007) Role of proteins in soil carbon and nitrogen storage: controls on persistence. Biogeochemistry 85:25-44. doi:10.1007/s10533-007-9102-6

Ryba SA, Burgess RM (2002) Effects of sample preparation on the measurement of organic carbon, hydrogen, nitrogen, sulphur and oxygen concentrations in marine sediments. Chemosphere 48:139-147.

Schofield HK (2015) A biogeochemical study of nutrient dynamics in artificial soil. PhD Thesis, University of Plymouth, Plymouth, UK; http://hdl.handle.net/10026.1/3766 Plymouth

Schollenberger CJ, Simon RH (1945) Determination of exchange capacity and exchangeable bases in soil - ammonium acetate method. Soil Science 59:13-24.

Schwarzenbach R, Gschwend P, Imboden D (1993) Environmental Organic Chemistry. John Wiley \& Sons, Inc., New York

Speight J, Lee S (2000) Environmental technology handbook. 2nd ed. Taylor \& Francis 


\section{New York}

Treseder K, Pytel M, Mappley M, Griffiths A, Pettitt T (2011) Evolution of Pest

Management Strategies in the Rain-Forest Biome at the Eden Project, the First 10

Years. Outlooks on Pest Management 22:22-31. doi:10.1564/22feb07

Vinther FP, Hansen EM, Eriksen J (2006) Leaching of soil organic carbon and nitrogen in sandy soils after cultivating grass-clover swards. Biology and Fertility of Soils 43:1219. doi:10.1007/s00374-005-0055-4

Watson CJ, Jordan C, Lennox SD, Smith RV, Steen RWJ (2000) Organic nitrogen in drainage water from grassland in northern Ireland. Journal of Environmental Quality 29:1233-1238.

White R (2006) Principles and Practice of Soil Science; The Soil as a Natural Resource. Blackwell Publishing, Oxford, UK

Yu WH, Li N, Tong DS, Zhou CH, Lin CX, Xu CY (2013) Adsorption of proteins and nucleic acids on clay minerals and their interactions: A review. Applied Clay Science 80-81:443-452. doi:http://dx.doi.org/10.1016/j.clay.2013.06.003 
Table 1. Concentrations of solid phase $\mathrm{N}$-fractions, and \% change, after 52 weeks; average values were calculated for a range of depth intervals within the soil column to give an integrated concentration. For ANOVA tests, results are expressed as * and ${ }^{\sharp}$ to indicate a significant difference $(\mathrm{p}<0.05)$ compared to S0, and a significant difference between $\mathrm{S} 1$ and $\mathrm{S} 2$ concentrations, respectively. With the exception of $\mathrm{NO}_{3}{ }^{-}$in S2, concentrations of Nfractions decreased over the experimental period and were significantly different at the end of the experiment. Addition of fertiliser had a significant effect only for TEN. S0 = freshly prepared soil; S1 = unfertilised soil; S2 = fertilised soil; TPN = total particulate nitrogen; TEN = total extractable nitrogen; $\mathrm{EON}=$ extractable organic nitrogen; $\mathrm{ENO}_{3}{ }^{-}=$extractable nitrate.

\begin{tabular}{|l|c|c|c|c|c|}
\hline \multirow{2}{*}{ Parameter } & \multirow{2}{*}{ S0 } & \multicolumn{2}{|c|}{ S1 } & \multicolumn{2}{c|}{ S2 } \\
\cline { 3 - 6 } & & Concentration & $\Delta(\%)$ & Concentration & $\Delta(\%)$ \\
\hline TPN $\left(\mathrm{mg} \mathrm{N} \mathrm{g}^{-1}\right)$ & $10 \pm 0.2$ & $9.48 \pm 1.55^{*}$ & -7.02 & $9.19 \pm 2.33^{*}$ & -9.95 \\
\hline TEN $\left(\mu \mathrm{g} \mathrm{N} \mathrm{g}^{-1}\right)$ & $253 \pm 14$ & $68.9 \pm 18.7^{* \pm}$ & -72.8 & $50.3 \pm 9.3^{*}$ & -80.1 \\
\hline${\text { EON }\left(\mu \mathrm{g} \mathrm{g}^{-1}\right)}^{2}$ & $246 \pm 14$ & $26.2 \pm 10.8^{*}$ & -89.3 & $37.0 \pm 15.5^{*}$ & -85.0 \\
\hline ENO $_{3}^{-}\left(\mu \mathrm{g} \mathrm{N} \mathrm{g}^{-1}\right)$ & $7.14 \pm 1.12$ & $20.0 \pm 13^{*}$ & 180 & $24.8 \pm 11.5^{*}$ & 247 \\
\hline
\end{tabular}


Figure 1

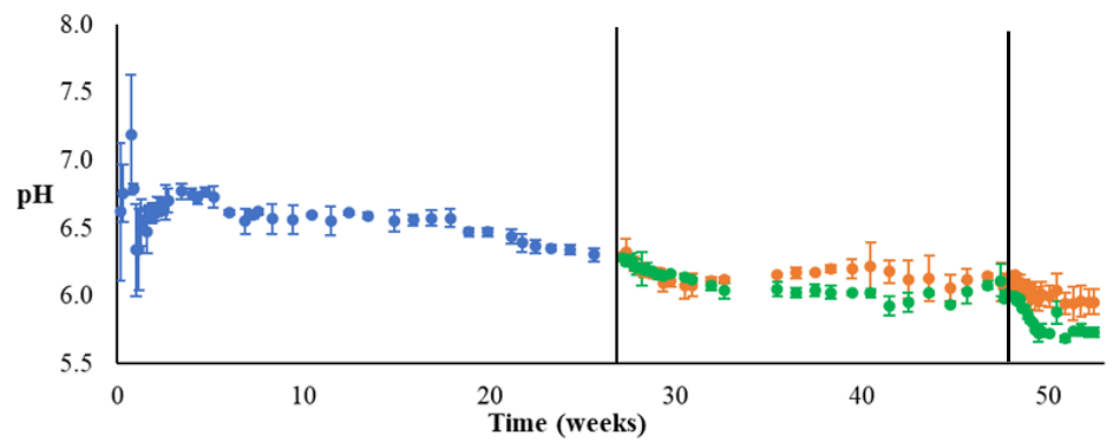


Figure 2

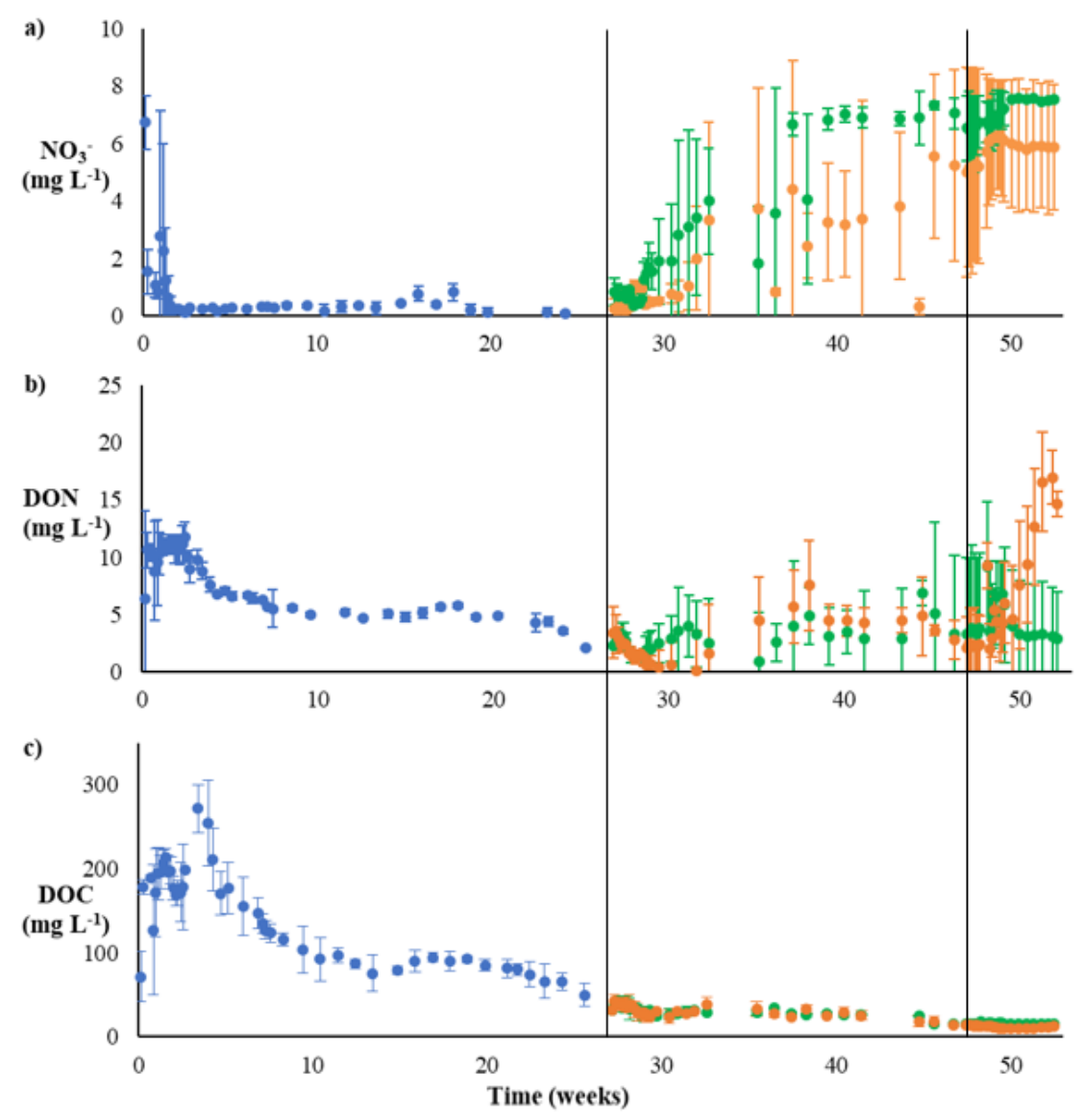


Figure 3

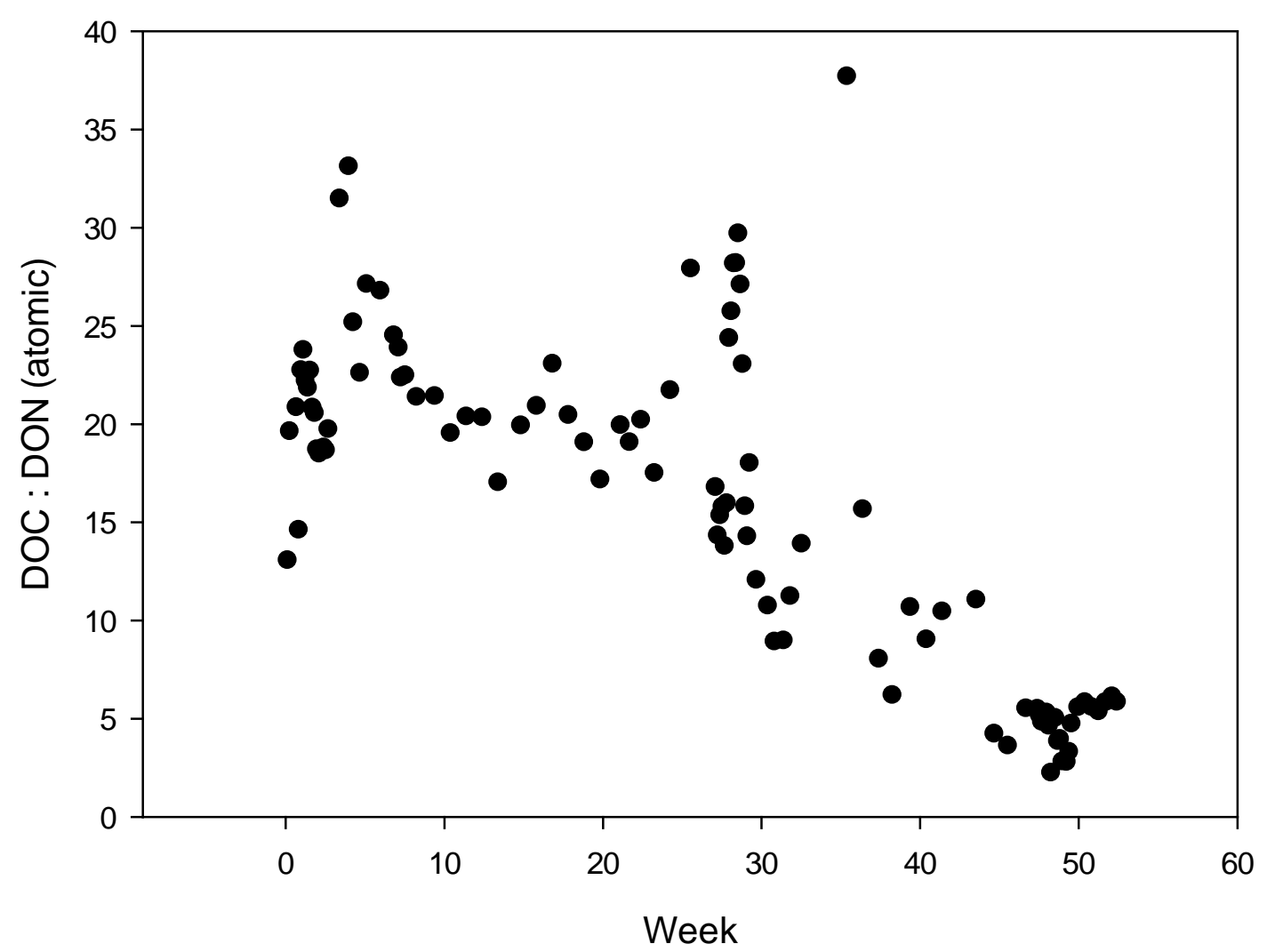

